\title{
MACIEJ BOCHEŃSKI
}

Uniwersytet Jagielloński, Krakowska Izba Adwokacka

\section{POMIĘDZY ZASADĄ POUFNOŚCI ZAWODOWEJ A OBOWIAZZKIEM DENUNCJACJI - CZY POLSKIE PRAWO LEKCEWAŻY, CZY CHRONI TAJEMNICĘ ZAWODOWA PSYCHOLOGA?}

Streszczenie: Poufność jest bez wątpienia jedną z najważniejszych zasad wykonywania zawodu psychologa. Prawo polskie gwarantuje ochronę tajemnicy zawodowej psychologów (także poprzez przepisy kodeksu karnego penalizujące jej naruszenie). Jednak to samo prawo (polski Kodeks karny) zmusza psychologów do przełamania zasady poufności, a to w przypadku powzięcia przez nich wiarygodnej informacji o określonych przestępstwach. Celem tej publikacji jest próba rozstrzygnięcia kolizji wartości pomiędzy zasadą przestrzegania tajemnicy zawodowej i zasadą bezpieczeństwa publicznego oraz dobra wymiaru sprawiedliwości. Wynik takiej analizy może być z pewnością pomocny dla psychologów w rozwiązaniu konfliktu między zawodową dyskrecją a obowiązkami prawnymi w zakresie zgłaszania przestępstw.

Slowa kluczowe: tajemnica zawodowa psychologa, etyka, prawo karne.

\section{ISTOTA TAJEMNICY ZAWODOWEJ PSYCHOLOGA - UWAGI OGÓLNE}

Istnienie tajemnicy zawodowej to z pewnością jeden z fundamentów wykonywania zawodu psychologa. Wrażliwe dane i informacje, z którymi w ramach wykonywania zawodu zapoznaje się psycholog, bez wątpienia powinny być w sposób należyty zabezpieczone przed ich ujawnieniem, czemu ma służyć zasada profesjonalnej dyskrecji (Bednarek, 2016; Gavaghan, 2007; Hudson-Allez, 2004; Jenkins, 2005; Popiel, Pragłowska, 2008; Younggren, Harris, 2008; Augustynowicz, 2008; Kermani, 1982).

Kwestia tajemnicy zawodowej pozostaje jednym z centralnych zagadnień etyki psychologa, bez względu na to, na jakiej sferze działalności psychologicznej koncentruje on swoją działalność zawodową. Właściwie każdy akt normatywny regulujący standardy etyki i deontologii zawodowej psychologa (Kermani, 1982; Chodof 1996) wprowadza zasadę tajemnicy zawodowej (zob. m.in. Kodeks Etyczno-Zawodowy Polskiego Towarzystwa Psychologicznego 1991; Kodeks Etyczny Psychoterapeutów Polskiego Towarzystwa Psychiatrycznego 2015; Kodeks Etyczny Polskiego Towarzystwa Terapii Poznawczej i Behawioralnej 2005). W piśmiennictwie podkreśla się, że tajemnica zawodowa stanowi fundament wykonywania zawodu psychologa, na którym

Adres do korespondencji: maciej.bochenski@uj.edu.pl, ORCID: https://orcid.org/00000003-2818-6719. 
opiera się zaufanie, konieczne w relacji psychologa z Klientem, szczególnie w przypadku prowadzenia przez psychologa psychoterapii (Bednarek, 2016; Fedorowicz, 2013; Jenkins, 2005; Popiel, Pragłowska, 2008; Younggren, Harris, 2008). Wyłącznie niezachwiane przekonanie Klienta o tym, że żadne z przekazanych psychologowi informacji (poza wypadkami zagrożenia zdrowia i życia) nie zostaną ujawnione, daje szansę realizacji celów i zadań, jakich podejmuje się psycholog (Bednarek, 2016; Chodoff, 1996; Fedorowicz, 2013; Gavaghan, 2007; Popiel, Pragłowska, 2008; Younggren, Harris, 2008).

Kwestia tajemnicy zawodowej psychologa nie umknęła również uwadze polskiego ustawodawcy w ramach formułowania prawnych ram wykonywania działalności psychologicznej (Górski, 2012, Świtała, 2014a, 2014b, 2014c). Zasada zawodowej dyskrecji i poufności zyskała rangę normy ustawowej, a to w art. 14 Ustawy z dnia 8 czerwca 2001 r. o zawodzie psychologa i samorządzie zawodowym psychologów (UoZPSZP 2001), w art. 50 Ustawy z dnia 19 sierpnia 1994 r. o ochronie zdrowia psychicznego, tj. z dnia 5 kwietnia 2017 r. (UoOZP 2017) oraz art. 14 Ustawy z dnia 6 listopada 2008 r. o prawach pacjenta i Rzeczniku Praw Pacjenta, tj. z dnia 8 czerwca 2017 r. (UoPPRPP 2017). Zgodnie z art. 14 pierwszego z wymienionych aktów normatywnych:

1. Psycholog ma obowiązek zachowania w tajemnicy informacji związanych z klientem, uzyskanych w związku z wykonywaniem zawodu.

2. Obowiązek zachowania tajemnicy zawodowej nie może być ograniczony w czasie.

3. Przepisu ust. 1 nie stosuje się, gdy:

1) poważnie jest zagrożone zdrowie, życie klienta lub innych osób,

2) tak stanowią ustawy.

Z kolei w świetle art. 50 UoOZP:

Osoby wykonujące czynności wynikające z niniejszej ustawy są obowiązane do zachowania w tajemnicy wszystkiego, o czym powezmą wiadomość w związku z wykonywaniem tych czynności, stosownie do odrębnych przepisów, a nadto z zachowaniem przepisów niniejszego rozdziału.

W przepisie art. 50 ust. 2 przywołanej ustawy przewidziano z kolei wyjątki od zasady wysłowionej w art. 50 ust. 1.

Art. 14 ust. 1 UoPPRPP, który może być uważany za podstawę zachowania tajemnicy zawodowej przez osoby wykonujące zawód medyczny, nieuregulowany odrębną ustawą (Świtała, 2014b), wprowadza zasadę, zgodnie z którą:

osoby wykonujące zawód medyczny są obowiązane zachować w tajemnicy informacje związane z pacjentem, w szczególności ze stanem zdrowia pacjenta.

W dalszych przepisach przewidziane są dopuszczalne odstępstwa od tej zasady.

\section{TAJEMNICA ZAWODOWA PSYCHOLOGA W POSTĘPOWANIACH CYWILNYM, KARNYM I ADMINISTRACYJNYM}

Tajemnica zawodowa psychologa, jako tajemnica prawnie chroniona, doznaje ochrony również w postępowaniach: cywilnym, administracyjnym i karnym (Rejman, 1996; Safjan, 1998), pozwalając co najmniej odmówić odpowiedzi na pytanie, a w określo- 
nych przypadkach także odmówić zeznań (zob. art. $261 \$ 2$ k.p.c., art. 82 k.p.a., 180 k.p.k.). Najdalej idącym przykładem ochrony tajemnicy zawodowej psychologa - działającego jako biegły - jest istnienie bezwzględnego zakazu dowodowego przesłuchania takiej osoby (Boratyńska, Górski, Sakowicz, 2014; Grzegorczyk, 2014; Hofmański, Sadzik, Zgryzek, 2011; Paprzycki, 2013; Razowski, 2010; Skorupka, 2018).

Podobnie art. 52 UoOZP ustanawia zakaz dowodowy wobec osób obowiązanych do zachowania tajemnicy, na okoliczność wypowiedzi osoby, wobec której podjęto czynności wynikające z ustawy co do popełnienia przez nią czynu zabronionego pod groźbą kary. Wspomniany zakaz stosuje się odpowiednio do lekarzy wykonujących czynności biegłego. W kontekście tego ostatniego przepisu warto wskazać na Postanowienie Sądu Najwyższego - Izby Karnej z dnia 20 kwietnia 2005 r. sygn. akt I KZP 6/05, w którym stwierdzono, że „Przepis art. 52 ust. 1 ustawy z dnia 19 sierpnia 1994 r. o ochronie zdrowia psychicznego dotyczy każdej osoby, która wykonuje czynności określone w tej ustawie; ustanawia on bezwzględny zakaz dowodowy, będąc przepisem szczególnym w stosunku do unormowania art. 180 k.p.k., a wobec tego takiej osoby nie można przesłuchać co do okoliczności przewidzianych w art. 52 ust. 1, nawet jeżeli wyrazi ona gotowość ujawnienia tego rodzaju tajemnicy zawodowej".

Odnosząc się w tym miejscu do wspomnianych regulacji art. $180 \$ 1$ k.p.k. i art. $180 \$ 2$ k.p.k. warto na marginesie wskazać, że tajemnica zawodowa psychologa doznaje na gruncie postępowania karnego mniejszej ochrony niż tajemnica zawodowa m.in. notariusza, adwokata, radcy prawnego, doradcy podatkowego oraz dziennikarza, a także lekarza. Wspomniane grupy zawodowe mogą być bowiem przesłuchiwane co do faktów objętych tą tajemnicą tylko wtedy, gdy jest to niezbędne dla dobra wymiaru sprawiedliwości, a zwolnienia z tajemnicy udzielić może wyłącznie Sąd (Górski, 2012). Natomiast psycholog może zostać zwolniony z tajemnicy także przez prokuratora i to bez konieczności spełnienia tak restrykcyjnych przesłanek, jakie ustanawia art. $180 \$ 2$ k.p.k. Sytuacja ta jest o tyle niezrozumiała, że przecież nierzadko rolą psychologa jest wykonywanie czynności o takim samym znaczeniu dla zdrowia psychicznego, czym dla zdrowia somatycznego interwencje lekarskie. Co bardziej istotne, zestawienie przepisów art. 14 Ustawy o zawodzie psychologa z analogicznym przepisem (art. 40) Ustawy o zawodach lekarza i lekarza dentysty wskazuje, że prawo w tym drugim przypadku przewiduje szerszy zakres wyjątków od zasady zawodowej dyskrecji. Oto bowiem:

1. Lekarz ma obowiązek zachowania w tajemnicy informacji związanych $\mathrm{z}$ pacjentem, a uzyskanych w związku z wykonywaniem zawodu.

2. Przepisu ust. 1 nie stosuje się, gdy:

1) tak stanowią ustawy;

2) badanie lekarskie zostało przeprowadzone na żądanie uprawnionych, na podstawie odrębnych ustaw, organów i instytucji; wówczas lekarz jest obowiązany poinformować o stanie zdrowia pacjenta wyłącznie te organy i instytucje;

3) zachowanie tajemnicy może stanowić niebezpieczeństwo dla życia lub zdrowia pacjenta lub innych osób;

4) pacjent lub jego przedstawiciel ustawowy wyraża zgodę na ujawnienie tajemnicy, po uprzednim poinformowaniu o niekorzystnych dla pacjenta skutkach jej ujawnienia; 
5) zachodzi potrzeba przekazania niezbędnych informacji o pacjencie lekarzowi sądowemu;

6) zachodzi potrzeba przekazania niezbędnych informacji o pacjencie związanych z udzielaniem świadczeń zdrowotnych innemu lekarzowi lub uprawnionym osobom uczestniczącym w udzielaniu tych świadczeń.

Wydaje się, że wspomniana okoliczność stanowi wyzwanie dla środowiska psychologów w Polsce, jako że dwa zawody, które z punktu widzenia celów i zadań oraz roli w życiu człowieka (ochrona zdrowia) korzystają - w zakresie zasad profesjonalnej dyskrecji - ze zróżnicowanego poziomu ochrony, przy czym te różnice jawią się jako nieuzasadnione. W ocenie autora likwidacja wzmiankowanych rozbieżności stanowić winna ważki cel psychologów w Polsce w zakresie formułowania postulatów de lege ferenda.

Wracając do przerwanego wątku należy podkreślić, że tajemnica zawodowa psychologa może w określonych sytuacjach uzyskać rangę tajemnicy bezwzględnej i absolutnej (tj. niepodlegającej uchyleniu w jakichkolwiek okolicznościach), choć co do zasady przepisy, które ją ustanawiają, wprost dopuszczają możliwość ujawnienia faktów objętych zawodową dyskrecją, m.in. w sytuacji zagrożenia życia Klienta lub innych osób.

Warto również dodać, że tajemnica zawodowa psychologa prócz tego, że jest prawnie zagwarantowana, to została również obwarowana prawnymi mechanizmami przewidującymi odpowiedzialność za jej złamanie.

\section{KONSEKWENCJE ZŁAMANIA TAJEMNICY ZAWODOWEJ PSYCHOLOGA}

Niewątpliwie najbardziej dotkliwe konsekwencje przewiduje Kodeks karny, który $\mathrm{w}$ art. 266 penalizuje ujawnienie prawnie chronionej tajemnicy zawodowej. Warto zatem wskazać, że zgodnie z treścią omawianego przepisu

Kto, wbrew przepisom ustawy lub przyjętemu na siebie zobowiązaniu, ujawnia lub wykorzystuje informację, z którą zapoznał się w związku z pełnioną funkcją, wykonywaną pracą, działalnością publiczną, społeczną, gospodarczą lub naukową, podlega grzywnie, karze ograniczenia wolności albo pozbawienia wolności do lat 2 .

Jakkolwiek ściganie wskazanego czynu następuje na wniosek pokrzywdzonego, to jednak nie budzi wątpliwości, że psycholog ujawniający informację, którą pozyskał w ramach wykonywania działalności zawodowej, naraża się na odpowiedzialność karną (Świtała, 2014a).

Nieco mniejszy ciężar gatunkowy niesie ze sobą odpowiedzialność cywilno-prawna. W doktrynie zwraca się uwagę na kumulatywny charakter roszczeń wynikających z przepisu art. 4 ust. 1 UoPPRPP i art. 448 k.c. oraz na możliwość korzystania także z niemajątkowych środków ochrony dóbr osobistych przewidzianych w art. 24 k.c., gdy złamanie tajemnicy godzi w czyjeś dobra osobiste (Świtała, 2014a). Poza wskazanymi możliwe jest również domaganie się odszkodowania na podstawie art. 415 k.c. w sytuacji wystąpienia szkody majątkowej na skutek niezachowania rygorów ochrony tajemnic zawodów medycznych (Kolasiński, 2002; Olejniczak, 2010; Wild, 2001). Jeżeli natomiast zobowiązanie do zachowania poufności traktować jako element umo- 
wy pomiędzy Klientem a psychologiem, to wskutek ujawnienia informacji objętych tajemnicą nie można wykluczyć także odpowiedzialności odszkodowawczej za niewykonanie zobowiązania, opartej na zasadzie art. 471 k.c.

Nie można nie wspomnieć również o sankcjach dyscyplinarnych, które mogą dotknąć osobę, która zlekceważyła, bądź choćby w niewystarczający sposób zabezpieczyła dane podlegające ochronie (Kermani, 1982). Dobitnie wskazują na to dokumenty stowarzyszeń stojących w Polsce na straży prawidłowości wykonywania zawodu psychologa. Można w tej materii wskazać Statut Polskiego Towarzystwa Psychologicznego (Statut PTP-2005), Statut Polskiego Towarzystwa Terapii Poznawczej i Behawioralnej (Statut PTTPB, 1998), a także i Regulamin Sądu Koleżeńskiego Polskiego Towarzystwa Psychologicznego (Regulamin Sądu PTP 2015).

$\mathrm{Z}$ punktu widzenia uregulowań prawnych tajemnica zawodowa psychologa w Polsce jawi się zatem jako dobrze zabezpieczona zasada wykonywania działalności psychologicznej. $Z$ uwagi jednak na fakt, że profesjonalna dyskrecja i poufność nie mają charakteru absolutnego, w swojej pracy psycholog napotkać może na trudne do rozwiązania problemy związane z koniecznością podjęcia decyzji, czy przydać prymat tajemnicy zawodowej, czy też tajemnicę tę złamać, w trosce o inne wartości (Gavaghan, 2007; Koocher, 2003; Kuo, 2009; Younggren, Harris, 2008; Mappes, Robb, Engels, 1985).

\section{ART. 240 K.K. I JEGO ZNACZENIE DLA TAJEMNICY ZAWODOWEJ PSYCHOLOGA}

O ile jednak w nauce psychologii i praktyce psychologicznej wypracowano standardy postępowania w sytuacji etycznego konfliktu wartości (Gavaghan, 2007; Gray, 2006; Greenberg, Buchbinder, Witztum, 2012; Hudson-Allez, 2004; Koocher, 2003; Popiel, Pragłowska, 2008; Younggren, Harris, 2008), o tyle znacznie poważniejszym problemem są sytuacje, w których psycholog zostaje niemal pozbawiony możliwości dokonania wyboru, a to wobec prawnego obowiązku ujawnienia tajemnicy zawodowej. Tak może być postrzegany art. 240 k.k., określany czasem nawet jako „obowiązek denuncjacji”" (Królikowski, Zawłocki, 2017; Plebanek, Rusinek, 2007; Stefański, 2017; Tyszkiewicz, 2018; Wilk, 1999; Wróbel, 2007). W brzmieniu art. 240 k.k. po nowelizacji, obowiązującej od 13 lipca 2017 r. znalazły się niektóre przestępstwa seksualne, m.in.: zgwałcenie zbiorowe, tzw. pedofilskie i kazirodcze oraz ze szczególnym okrucieństwem (art. $197 \$ 3$ i $\$ 4$ k.k.), seksualne wykorzystanie bezradności (art. 198 k.k.) oraz obcowanie płciowe z małoletnim poniżej 15. roku życia (art. 200 k.k.).

Szczególnych trudności może przydawać ten ostatni przepis. Jeżeli zważyć, że dobrowolne współżycie dwojga osób: 17-latka i niespełna 15-latki (osób tzw. chodzących ze sobą) wyczerpuje znamiona typu czynu z art. 200 k.k. (Beisert, 2011; Bocheński, 2016; Hall, Hall, 2007; Mozgawa, Budyn-Kulik, 2006; Seto, 2004, 2008, 2009; Warylewski, 2006a, 2006b, 2007; Warylewski, 2001a, 2001b) i że z perspektywy znamion typu czynu zabronionego z art. $200 \mathrm{k}$.k. sprawcą takiego przestępstwa wcale nie musi być „pedofil” w rozumieniu medycznych klasyfikacji diagnostycznych (Beisert, 2011; Bocheński, 2016; Mozgawa, Budyn-Kulik, 2006; Seto, 2004, 2008, 2009; Warylewski, 2006a, 2006b, 2007), jako nader aktualne staje się pytanie o to, czy istotnie art. 240 k.k. uchyla obowiązek zachowania tajemnicy przez psychologa. W tym kontekście rodzi się ze wszech miar zasadne i uprawnione pytanie o zakres kryminalizacji 
omawianego art. 240 k.k., a przede wszystkim o stosunek tego przepisu do norm ustanawiających obowiązek zachowania tajemnicy zawodowej. Czy wartość w postaci zaufania koniecznego do należytego wykonywania zawodu, czy zasada lojalności względem Klienta winna doznawać ograniczeń w konflikcie z innymi wartościami bądź też dla tzw. dobra wymiaru sprawiedliwości.

Trzeba w tym miejscu podkreślić, że - przez wzgląd na umiejscowienie w systematyce Kodeksu karnego - nie budzi większych wątpliwości doktryny, że to właśnie to ostatnie stanowi główne dobro prawne chronione przez art. 240 k.k. Głównym dobrem prawnym chronionym w przypadku omawianego przepisu jest interes wymiaru sprawiedliwości wyrażający się w dążeniu do tego, aby każdy zamach na dobra prawne chronione przepisami wymienionymi w art. $240 \$ 1 \mathrm{k}$.k. został wykryty, a sprawca ujęty (Królikowski, Zawłocki, 2017; Mozgawa, 2017; Piórkowska-Flieger, 2017; Razowski, 2017; Szewczyk, 2006). Jedynie dla porządku można wskazać, że jako dodatkowy przedmiot ochrony, w wypadkach zawiadomienia o karalnym przygotowaniu lub usiłowaniu wskazuje się dobro chronione przepisem szczególnym wymienionym w art. 240 k.k. (Królikowski, Zawłocki, 2017; Szewczyk, 2006).

Analizując omawianą problematykę, nie można oprzeć się wrażeniu, że część odpowiedzialności za wykrywanie przestępstw (co stanowi przecież zadanie organów władzy publicznej) zostaje przeniesiona przez ustawodawcę na obywatela, w szczególności na osoby zaufania publicznego, zobowiązane z racji wykonywanego zawodu do zachowania tajemnicy zawodowej. Nie sposób nie dostrzec też pewnej niekonsekwencji ustawodawcy $-\mathrm{z}$ jednej strony bowiem zabezpiecza on stosownymi regulacjami prawnymi tajemnicę zawodową psychologa i rozmaitymi sankcjami obwarowuje jej złamanie, z drugiej poszerza katalog czynów objętych prawnym „obowiązkiem denuncjacji”, zwiększając potencjalny zakres sytuacji, w których psycholog będzie musiał zmierzyć się z konfliktem pomiędzy uczynieniem zadość obowiązkom płynącym z art. 240 k.k. a zasadą nieujawniania tajemnicy zawodowej.

Dotychczasowe rozważania prowadzą nieuchronnie do konieczności udzielenia, bądź choćby próby udzielenia, odpowiedzi na pytanie, czy wobec powzięcia przez psychologa w ramach wykonywanego przezeń zawodu wiarygodnej wiadomości o jednym z czynów wyszczególnionych w art. $240 \mathrm{k} . \mathrm{k}$. winien on dać prymat obowiązkom wynikającym z tego przepisu i jednocześnie uchronić się przed ryzykiem poniesienia odpowiedzialności karnej, czy też pozostać w zgodzie z najważniejszą bodaj regułą etyki i deontologii zawodowej i nie ujawniać takiej informacji organom ścigania. Czy decyzja w tym przedmiocie winna zależeć od rodzaju czynu, o którym wiadomość powziął psycholog? W kontekście sytuacji, w której psycholog może dowiedzieć się, że jego nieco ponad 17-letni Klient współżyje seksualnie ze swoją niespełna 15-letnią dziewczyną wskazane pytanie nabiera większej aktualności.

Opisana forma czynu stanowiącego wszakże przestępstwo z art. $200 \mathrm{k} . \mathrm{k}$. - i to dość częsta w praktyce (Beisert, 2011; Bocheński, 2016; Mozgawa, Budyn-Kulik, 2006) wobec faktu, że współżycie w/w osób jest w pełni dobrowolne, trudniejsza będzie do jednoznacznej oceny z perspektywy tego dylematu. Istnieją bowiem poważne wątpliwości, czy - także z perspektywy biologii i psychologii rozwojowej (Bocheński, 2016) istotnie dochodzi w opisanej sytuacji do ataku na jakiekolwiek dobro prawne, a w szczególności czy dochodzi do zagrożenia zdrowia „ofiary” (Bielski, 2008a, 2008b; Bocheński, 2016; Filar, 2002, 2010; Gardocki, 2010; Kunicka-Michalska, Wojciechowska, 2001). Wątpliwości można mnożyć dalej. Jak powinien zachować się psycholog, któremu fakt pokrzywdzenia jednym z przestępstw wyszczególnio- 
nych w art. $240 \$ 1$ k.k. ujawnia osoba pokrzywdzona? Trudno zlekceważyć klauzulę $\mathrm{z}$ art. $240 \$ 2 \mathrm{a}$ k.k., zgodnie z którą

Nie podlega karze pokrzywdzony czynem wymienionym w $₫ 1$, który zaniechał zawiadomienia o tym czynie.

Skoro zatem sam pokrzywdzony podjął decyzję o niezawiadomieniu organów ścigania, to czy psycholog powinien występować w pozycji tego, który „wie lepiej” i w sposób oczywisty lekceważyć wolę swojego klienta wyłącznie przez wzgląd na możliwą odpowiedzialność karną? Sprawę może dodatkowo komplikować fakt, że pokrzywdzony jest małoletni, choć nie można wykluczyć także i tego, że przestępstwo miało miejsce, kiedy ofiara była małoletnia, ale do psychologa uczęszcza już po uzyskaniu pełnoletności. Czy obowiązek z art. $240 \$ 1$ k.k. należy rozumieć w taki sposób - który może przecież wypaczyć cały sens udzielania pomocy psychologicznej - że psycholog powinien już przy pierwszym kontakcie pouczyć klienta, że jeśli dowie się w ramach spotkań o przestępstwie popełnionym na szkodę klienta, to niezależnie od stanowiska klienta w tym przedmiocie zawiadomi organy ścigania?

Przystępując do sygnalizowanej próby udzielenia czytelnikowi odpowiedzi na pytanie: ,jak w takiej sytuacji postąpić...?”, należy wskazać, że ustawowe uregulowanie tajemnicy zawodowej psychologa z definicji wskazuje, że nie jest to tajemnica absolutna.

W doktrynie prawa karnego zaznaczył się spór co do obowiązku denuncjacji spoczywającym na przedstawicielach zawodów zaufania publicznego obowiązanych do zachowania tajemnicy zawodowej (spór co prawda zarysował się na tle sytuacji prawnej adwokata, natomiast w literaturze słusznie rozszerza się zakres dyskusji także na inne zawody, które cechują się obowiązkiem zachowania zawodowej dyskrecji), który powziął informację o jednym z czynów opisanych w art. $240 \$ 1$ k.k. w związku z wykonywaniem czynności zawodowych. Zdaniem jednych adwokat - którego pierwotnie dotyczyła dyskusja - jest zwolniony z obowiązku denuncjacji (Gardocki, 2008; Kunicka-Michalska, 2001; Szewczyk, 2006), zdaniem drugich - nie (Marek, 2010; Zgoliński, 2016). Pierwszy pogląd wydaje się bardziej uzasadniony. Słusznie się bowiem zauważa, nie tylko zresztą w odniesieniu do adwokatów, ale również radców prawnych, lekarzy, dziennikarzy itd., że zawodowa dyskrecja w kolizji z interesami wymiaru sprawiedliwości powinna mieć pierwszeństwo, a kolizję między obowiązkiem zachowania tajemnicy zawodowej a obowiązkiem denuncjacji z art. $240 \$ 1$ k.k. należy rozstrzygać na korzyść tej pierwszej powinności.

$\mathrm{Z}$ całokształtu regulacji prawnej wynika, że ustawodawca generalnie przyznaje pierwszeństwo zawodowej dyskrecji (Dukiet-Nagórska, 2002; Plebanek, Rusinek, 2007). W doktrynie podnosi się również argument wykładni systemowej, że przepisy art. $180 \$ 1$ i 2 k.p.k. nie pozostawiają wątpliwości co do prymatu tajemnicy zawodowej nad interesem wymiaru sprawiedliwości. Tezę tę wzmacniają argumenty wynikające z konstytucyjnej zasady proporcjonalności (art. 31 ust. 3 Konstytucji RP), która pozwala ograniczyć korzystanie z konstytucyjnych wolności i praw tylko wtedy, gdy jest to konieczne dla bezpieczeństwa państwa, porządku publicznego, ochrony środowiska, zdrowia i moralności publicznej albo wolności i praw innych osób. $Z$ tej regulacji można wysnuć wniosek, że co do zasady zawodowa dyskrecja w kolizji z interesami wymiaru sprawiedliwości winna mieć pierwszeństwo i tylko wyjątkowo możliwe jest poświęcenie jej dla realizacji celów procesu karnego (Boratyńska, Górski, Sakowicz, 2014; Grzegorczyk, 2014; Hofmański, Sadzik, Zgryzek, 2011; Paprzycki, 2013; Plebanek, Rusinek, 2007; Rusinek, 2017). 
W literaturze - odnośnie do sytuacji prawnej psychologa - wyrażono pogląd, że w takim przypadku ,jako zasadę należy przyjąć, że powiadomienie o popełnieniu czynu zabronionego na osobie pacjenta oparte być musi na zgodzie pokrzywdzonego pacjenta" i taka denuncjacja w żadnym razie nie stanowi obowiązku osoby wykonującej zawód medyczny (Dukiet-Nagórska, 2002; Świtała, 2014a, 2014b, 2014c). Z tego punktu widzenia problem niestety nie traci na aktualności w przypadku Klienta, który w kontakcie z psychologiem przyznaje się do popełnienia czynu zabronionego.

Wracając do podstawowego przepisu statuującego tajemnicę zawodową psychologa:

1. Psycholog ma obowiązek zachowania $\mathrm{w}$ tajemnicy informacji związanych z klientem, uzyskanych w związku z wykonywaniem zawodu.

2. Obowiązek zachowania tajemnicy zawodowej nie może być ograniczony w czasie.

3. Przepisu ust. 1 nie stosuje się, gdy:

1) poważnie jest zagrożone zdrowie, życie klienta lub innych osób,

2) tak stanowią ustawy.

W przypadku każdego z czynów wyszczególnionych w art. 240 k.k., w przypadku którego spełniona jest równocześnie przesłanka „poważnego zagrożenia zdrowia, życia klienta lub innych osób" można wskazać, że samodzielną podstawę uchylenia się od obowiązku zachowania tajemnicy daje art. 14 ust. 3 pkt 1 UoZP. Trzeba jednak w tym miejscu podkreślić z całą stanowczością, że literalne brzmienie wskazanego przepisu przesądza, że zagrożenie musi być poważne (a zatem: budzące obawę, obarczone dużym ryzykiem), jak również realnie i obiektywnie istniejące w czasie, w którym psycholog dowiaduje się o określonych faktach. Skoro ustawodawca wprost wskazuje, że psycholog nie ma obowiązku zachowania w tajemnicy informacji związanych z klientem uzyskanych w związku z wykonywaniem zawodu, gdy poważnie jest zagrożone zdrowie, życie klienta lub innych osób, to nie powinno budzić wątpliwości, że zasada zawodowej dyskrecji i poufności jest uchylona wyłącznie jeśli niebezpieczeństwo istnieje w teraźniejszości lub „na przyszłość”. To z kolei oznacza brak uchylenia stosowania art. 14 ust. 1 UoZP, gdy psycholog dowiaduje się o czynach z przeszłości, które wszakże nie trwają obecnie i nie będą kontynuowane w przyszłości.

Trzeba w tym miejscu dla porządku zaznaczyć, że dla oceny prawdopodobieństwa ponownego popełnienia przestępstwa wypracowano w nauce stosowne narzędzia (Bocheński, 2016). Wydaje się jednak, że oczekiwanie, aby psycholog dowiedziawszy się o popełnieniu w przeszłości przez swojego Klienta przestępstwa miał obowiązek prowadzić szeroko zakrojone i dogłębne badania, aby ustalić, czy po stronie tegoż Klienta istnieje znaczne ryzyko recydywy, jest zbyt daleko idące. Rozsądek podpowiada, aby sposobem stwierdzenia „poważnego zagrożenia” były konkretne, realne deklaracje Klienta dotyczące uczynienia krzywdy sobie, bądź innym. We wszystkich "granicznych" przypadkach i takich, gdzie owego "poważnego zagrożenia” prima facie nie ma (jak choćby przywołany kazus „,hodzących ze sobą” i podejmujących współżycie seksualne osób, z których jedna ukończyła 17 lat, druga zaś jest w wieku niespełna 15 lat), istotna będzie odpowiedź na pytanie: czy art. 240 k.k. wyczerpuje hipotezę, pozwalającą na uchylenie się obowiązku zachowania tajemnicy zawodowej przez psychologa, wskazaną w art. 14 ust. 3 pkt 2 UoZP? Czy zawarta w tym przepisie klauzula, w „tak stanowią ustawy" oznacza wyłącznie przepisy, które wprost wyłączają obowiązek zachowania tajemnicy zawodowej, o którym mowa w art. 14 ust. 1 UoZP, czy też zwrot 
ten obejmuje te wszystkie przypadki, w których przepisy ustawy (nakładane przez te przepisy obowiązki lub zakazy) są nie do pogodzenia z obowiązkiem, o którym mowa w art. 14 ust. 1 UoZP.

Z uwagi na fakt, że zasadą wykonywania zawodu psychologa jest zachowanie tajemnicy, jej zaś uchylenie (także na podstawie art. 14 ust. 3 pkt 2 UoZP, należy poczytywać jako wyjątek, to zgodnie z zasadami dokonywania wykładni prawa, należałoby interpretować ów wyjątek zawężająco. Zatem wydaje się zasadne, aby przepis ustawy, o której mowa w art. 14 ust. 3 pkt 2 UoZP, wprost uchylał obowiązek zachowania tajemnicy, jak w przypadku art. 6 ust. 4 Ustawy z dnia 26 maja 1982 r. Prawo o Adwokaturze w brzmieniu: Obowiązek zachowania tajemnicy zawodowej nie dotyczy informacji udostępnianych na podstawie przepisów ustawy z dnia 16 listopada $2000 \mathrm{r}$. o przeciwdziałaniu praniu pieniędzy oraz finansowaniu terroryzmu (Dz.U. z 2017 r. poz. 1049) - w zakresie określonym tymi przepisami. Przepis ten można wskazać jako przykład regulacji, która w pełni przystaje do omawianego problemu - tj. uchyla ściśle określony i wprost wskazany obowiązek, gdy „tak stanowią ustawy”. Przepis art. 240 k.k. takiego wprost wyrażonego uchylenia tajemnicy zawodowej nie przewiduje, a nadto stanowi przepis ogólny, wobec szczególnych przepisów Ustawy o zawodzie psychologa, zatem wydaje się, że nie takiej sytuacji dotyczy norma wysłowiona przez art. 14 ust. 3 pkt 2 UoZP.

Sytuację prawną psychologów (członków zespołów interdyscyplinarnych funkcjonujących na podstawie Ustawy z dnia 29 lipca 2005 r. o przeciwdziałaniu przemocy w rodzinie) komplikuje dodatkowo fakt, że wśród ustawowych zadań wspomnianych zespołów znajduje się inicjowanie interwencji w środowisku dotkniętym przemocą w rodzinie oraz inicjowanie działań w stosunku do osób stosujących przemoc w rodzinie. Oznacza to, że ponownie psycholog zostaje postawiony przed konfliktem wartości w postaci tajemnicy zawodowej oraz obowiązków ustawowych i celów Ustawy o przeciwdziałaniu przemocy w rodzinie. Wydaje się, że w sytuacjach (podobnie jak wskazanych wcześniej) trwającego stanu poważnego zagrożenia zdrowia, życia klienta lub innych osób podstawę do uchylenia obowiązku zachowania tajemnicy zawodowej daje samodzielnie art. 14 ust 3 pkt 1 UoZP. W sytuacji, w której takiego zagrożenia (o takim natężeniu, bądź aktualnie trwającego) nie da się stwierdzić, wydaje się, że prymat winno przydać się zasadzie zawodowej dyskrecji, wszak nie wolno tracić z pola widzenia faktu, że na mocy art. 9a ust. 3 pkt 3 Ustawy o przeciwdziałaniu przemocy w rodzinie w skład zespołu interdyscyplinarnego wchodzi przedstawiciel Policji, który z definicji ma nie tylko prawo, ale i obowiązek wszczynania stosownych postępowań w razie stwierdzenia możliwości popełnienia przestępstwa.

Autor tej publikacji przychyla się do stanowiska, że obowiązek nakładany przez art. 240 k.k., nie uchyla tajemnicy zawodowej psychologa, w tych przypadkach, w których przepisy ustanawiające tę tajemnicę (vide art. 14 UoZP) nie dają podstaw do jej uchylenia. Trzeba jednak - dla naukowej rzetelności - z całą stanowczością wskazać, że istnieje pogląd przeciwny, choć jak się wydaje mniejszościowy (Marek, 2010; Zgoliński, 2016). Trzeba również przywołać stanowisko Trybunału Konstytucyjnego (wyrażone w kontekście tajemnicy zawodowej radcy prawnego), który uznał, że w konflikcie dwóch wartości: dobra wymiaru sprawiedliwości oraz dobra klienta powierzającego swemu pełnomocnikowi poufną informację, nie można nadać tej drugiej bezwzględnego prymatu.

Dlatego też TK stwierdził, że art. $180 \$ 2$ k.p.k. pozwala na zwolnienie radcy prawnego z tajemnicy zawodowej i jest zgodny z art. 2, art. 17, art. 31 ust. 3, art. 41 
ust. 1, art. 45 ust. 1, art. 49 i art. 51 ust. 2 Konstytucji RP (wyr. TK z 22.11.2004 r., SK 64/03, Dz.U. Nr 255, poz. 2568). Stanowisko Trybunału Konstytucyjnego - jakkolwiek trudne, a być może nawet niemożliwe do zaakceptowania (choćby dla środowiska adwokackiego) pozwala wnioskować o możliwym kierunku interpretacji podobnych konfliktów wartości w przypadku psychologa, choć dla przesądzenia omawianej problematyki w sposób jednoznaczny i wiążący użyteczna byłaby interwencja wykładnicza Sądu Konstytucyjnego bądź Sądu Najwyższego.

\section{BIBLIOGRAFIA}

Augustynowicz, A. (2008). Tajemnica zawodowa lekarza a współdziałanie z organami ścigania. Prawo i Medycyna, 4, 8398.

Bednarek, D. (2016). Zawód psycholog. Regulacje prawne i etyka zawodowa. Warszawa: PWN.

Beisert, M. (2011). Pedofilia. Geneza i mechanizm zaburzenia. Sopot: GWP.

Bielski, M. (2008a). Komentarz do art. 197 k.k. W: A. Zoll (red.), Kodeks Karny. Część szczególna. Komentarz. Tom II (s. 571631). Warszawa: Wolters Kluwer.

Bielski, M. (2008b). Wykładnia znamion „obcowanie płciowe” i „inna czynność seksualna" w doktrynie i orzecznictwie sądowym. Czasopismo Prawa Karnego i Nauk Penalnych, 1, 211-228.

Bocheński, M. (2016). Prawnokarna reakcja wobec sprawców przestępstw z art. $197 \mathrm{KK}$ $i$ art. $200 \mathrm{KK} w$ świetle teorii $i$ badań empirycznych. Warszawa: CH Beck.

Boratyńska, K.T., Górski, A., Sakowicz, A. (2014). Kodeks postępowania karnego. Komentarz. Warszawa: CH Beck.

Chodoff, P. (1996). Ethical dimensions of psychotherapy: A personal perspective. American Journal of Psychotherapy, 50(3), 298-310.

Dukiet-Nagórska, T. (2002). Lekarski obowiązek współdziałania z organami ścigania a tajemnica lekarska. Prawo i Medycyna, 12, 9-25.

Filar, M. (2002). Seksualne wykorzystywanie dzieci w świetle polskiego kodeksu karnego (na tle prawnoporównawczym). Dziecko Krzywdzone, 1, 39-51.

Filar, M. (2006). „Druga” nowelizacja Kodeksu karnego w zakresie tzw. przestępstw seksualnych. Państwo i Prawo, 3, 39-55.
Filar, M. (2010). Polityka kryminalna czy polityka? (Nowelizacja Kodeksu karnego w zakresie przestępstw seksualnych). W: V. Konarska-Wrzosek, J. Lachowski, J. Wójcikiewicz (red.), Węztowe problemy prawa karnego, kryminologii $i$ polityki kryminalnej. Ksiegga pamiątkowa ofiarowana Profesorowi Andrzejowi Markowi (s. 845-846). Warszawa: Wolters Kluwer.

Gardocki, L. (2008). Prawo karne. Warszawa: $\mathrm{CH}$ Beck.

Gardocki, L. (2010). Prawo karne. Warszawa: $\mathrm{CH}$ Beck.

Gavaghan, C. (2007). Dangerous patients and duties to warn: a European human rights perspective. European Journal of Health Law, 14, 113-130.

Górski, A. (2012). Lekarz w procesie karnym. W: P. Kardas, T. Sroka, W. Wróbel (red.), Państwo prawa i prawo karne. Ksiega Jubileuszowa Profesora Andrzeja Zolla (s. 1587-1601). Warszawa: Wolters Kluwer.

Gray, A. (2006). Confidentiality: a contribution to the debate. British Journal of Psychotherapy, 22(3), 363-372.

Greenberg, D., Buchbinder, J.T., Witztum, E. (2012). Arranged matches and mental illness: Therapists' dilemmas. Psychiatry, 75(4), 342-354.

Grzegorczyk, T. (2014). Kodeks postępowania karnego. Tom I. Artykuty 1-467. Komentarz. LEX/el (dostęp: 24.01.2018).

Hall, R.C.W., Hall, R.C.W. (2007). A profile of pedophilia: Definition, characteristics of offenders, recidivism, treatment outcomes, and forensic issues. Mayo Clinic Proceedings, 82(4), 457-471.

Hofmański, P., Sadzik, E., Zgryzek, K. (red.). (2011). Kodeks postepowania karnego. Ko- 
mentarz do 1-296. Tom I. Warszawa: $\mathrm{CH}$ Beck.

Hudson-Allez, G. (2004). Threats to psychotherapeutic confidentiality: Can psychotherapists in the UK really offer a confidentiality ethic to their clients? Psychodynamic Practice, 10(3), 317-331.

Jenkins, P. (2005). Aspects of the external frame: psychodynamic psychotherapy and the law. Psychodynamic Practice, 11(1), 41-56.

Kermani, E.J. (1982). Court rulings on psychotherapists. American Journal of Psychotherapy, XXXVI, 2, 248-255.

Kolasiński, M. (2002). Ochrona dóbr osobistych w prawie medycznym. Prawo i Medycyna, 11, 42-52.

Koocher, G.P. (2003). Ethical issues in psychotherapy with adolescents. Journal of Clinical Psychology: In Session, 59(11), 1247-1256.

Królikowski, M., Zawłocki, R. (red.). (2017). Kodeks karny. Część szczególna. Tom II. Komentarz. Art. 222-316. Warszawa: $\mathrm{CH}$ Beck.

Kunicka-Michalska, B., Wojciechowska, J. (2001). Przestępstwa przeciwko wolności, wolności sumienia $i$ wyznania, wolności seksualnej i obyczajności oraz czci i nietykalności cielesnej. Rozdziaty XXIII, XXIV, XXV i XXVII Kodeksu karnego. Komentarz. Warszawa: Beck.

Kuo, F. (2009). secrets or no secrets: confidentiality in couple therapy. The American Journal of Family Therapy, 37, 351354.

Mappes, D.C., Robb, G.P., Engels, D.W. (1985). Conflicts between ethics and law in counseling and psychotherapy. Journal of Counseling and Development, 64, 246-252.

Marek, A. (2010). Kodeks karny, Komentarz. Warszawa: Wolters Kluwer.

Mozgawa, M. (2017). Komentarz do Art. 240 k.k. W: M. Mozgawa (red.), Kodeks karny. Komentarz aktualizowany [online], Lex/el (dostęp: 24.01.2018).

Mozgawa, M., Budyn-Kulik, M. (2006). Prawnokarne aspekty pedofilii. Analiza dogmatyczna i wyniki badań empirycznych. Czasopismo Prawa Karnego i Nauk Penalnych, 2, 43-78.
Olejniczak, A. (2010). Komentarz do art. 448 Kodeksu cywilnego. W: A. Kidyba (red.), Kodeks cywilny. Komentarz. T. III. Zobowiązania - część ogólna, Lex/ el (dostęp: 24.01.2018).

Paprzycki, L.K. (2013). Kodeks postępowania karnego. Tom I. Komentarz do art. 1-424, LEX/el (dostęp: 24.01.2018).

Piórkowska-Flieger, J. (2017). Komentarz do Art. 240 k.k. W: T. Bojarski (red.), Kodeks karny. Komentarz, Lex/el (dostęp: 24.01.2018).

Plebanek, E., Rusinek, M. (2007). Ujawnienie tajemnicy zawodowej w procesie karnym a odpowiedzialność karna, Czasopismo Prawa Karnego i Nauk Penalnych, Rok XI, 1, 73-99.

Razowski, T. (2017). Komentarz do Art. 240 k.k. W: J. Giezek (red.), Kodeks karny. Część szczególna. Komentarz, Lex/el (dostęp: 24.01.2018).

Razowski, T. (2010). Zwolnienie świadka z obowiązku zachowania tajemnicy zawodowej w procesie karnym. Prokuratura i Prawo, 7-8, 142-149.

Rejman, G. (1996). Tajemnica lekarska. Studia Iuridica, XXXI, 147-188.

Rusinek, M. (2017). Tajemnica zawodowa $i$ jej ochrona $w$ polskim procesie karnym, Lex/el (dostęp: 24.01.2018).

Safjan, M. (1998). Prawo i medycyna. Ochrona praw jednostki a dylematy wspótczesnej medycyny. Warszawa: Oficyna Naukowa.

Seto, M.C. (2004). Pedophilia and sexual offenses against children. Annual Review of Sex Research, 15, 321-361.

Seto, M.C. (2008). Pedophilia and sexual offending against children. Theory, assessment and intervention. Washington DC: American Psychological Association.

Seto, M.C. (2009). Pedophilia. Annual Review of Clinical Psychology, 5, 391-407.

Skorupka, J. (red.). (2018). Kodeks postępowania karnego. Komentarz. Warszawa: $\mathrm{CH}$ Beck.

Stefański, R.A. (2017). Kodeks karny. Komentarz. Warszawa: CH Beck.

Szewczyk, M. (2000a). Kilka uwag dotyczących przestępstw przeciwko wymiarowi sprawiedliwości. Prokuratura i Prawo, 6, 23-27. 
Szewczyk, M. (2000b). Prawnokarna ochrona tajemnicy zawodowej lekarza. Czasopismo Prawa Karnego i Nauk Penalnych, 1, 161-172.

Szewczyk, M. (2006). Komentarz do art. 240 k.k. W: A. Zoll, Kodeks karny, Komentarz. t. 2, Lex/el (dostęp: 24.01.2018).

Świtała, K. (2014a). Tajemnice zawodów medycznych - podstawowa charakterystyka. Monitor Prawniczy, 11, Legalis/el (dostęp: 24.01.2018).

Świtała, K. (2014b). Wyjątki od obowiązku zachowania tajemnic zawodów medycznych. Monitor Prawniczy, 12, Legalis/el (dostęp: 24.01.2018).

Świtała, K. (2014c). Katalog tajemnic związanych z wykonywaniem zawodów medycznych. Monitor Prawniczy, 13, Legalis/el (dostęp: 24.01.2018).

Tyszkiewicz, L. (2018). Komentarz do Art. 240 k.k. W: M. Filar (red.), Kodeks karny. Komentarz, Lex/el (dostęp: 24.01.2018).

Warylewski, J. (2001a). Przestępstwa seksualne. Gdańsk: Wydawnictwo Uniwersytetu Gdańskiego.

Warylewski, J. (2001b). Przestępstwa przeciwko wolności seksualnej i obyczajności. Rozdziat XXV. Komentarz. Warszawa: Beck.

Warylewski, J. (2006a). Problematyka właściwej reakcji karnej na zachowania związane $\mathrm{z}$ godzeniem w wolność seksualną lub obyczajność, referat wygłoszony na IV Polskim Kongresie Penitencjarnym, Kalisz 22-24 listopada
2006 r.: http://arch.prawo.ug.edu.pl/ index.php?id=200\&pu=2346 (dostęp: 24.01.2018).

Warylewski, J. (2006b). Nowelizacje kodeksu karnego z 1997 r. w zakresie przestępstw seksualnych oraz ich konsekwencje. W: T. Bojarski, K. Nazar (red.), Zmiany w polskim prawie karnym po wejściu w życie kodeksu karnego z 1997 r. (s. 229-247). Lublin: Wydawnictwo UMCS.

Warylewski, J. (2007). Reakcja karna na przestępstwa seksualne. Przegląd Więziennictwa Polskiego, 54, 34-44.

Wild, M. (2001). Ochrona prywatności w prawie cywilnym (koncepcja sfer a prawo podmiotowe). Państwo $i$ Prawo, 4, 54-72.

Wilk, L. (1999). Obowiązek denuncjacji w prawie karnym. Prokuratura i Prawo, $1,21-40$.

Wróbel, W. (2007). Komentarz do art. 240 k.k. W: A. Zoll (red.), Kodeks karny, Komentarz, t. II, Lex/el (dostęp: 24.01.2018).

Younggren, J.N., Harris, E.A. (2008). Can you keep a secret? Confidentiality in psychotherapy. Journal of Clinical Psychology: In Session, 64(5), 589-600.

Zgoliński, I. (2016). Komentarz do Art. 240 k.k. W: V. Konarska-Wrzosek (red.), Kodeks karny. Komentarz, Lex/el (dostęp: 24.01.2018).

\section{Cytowane akty normatywne:}

Kodeks Etyczno-Zawodowy Psychologa, Polskiego Towarzystwa Psychologicznego 1991, http://www.ptp.org.pl/modules.php? name $=$ News $\&$ file $=$ article\&sid=29 (dostęp: 24.01.2018).

Kodeks Etyczny Polskiego Towarzystwa Terapii Poznawczej i Behawioralnej 2005 http://www.pttpb.pl/dokumenty/kodeks-etyczny/ (dostęp: 24.01.2018).

Kodeks Etyczny Psychoterapeutów Polskiego Towarzystwa Psychiatrycznego 2015, http://static2.medforum.pl/upload/file/KODEKS\%20ETYCZNY\%20PSYCHOTERAPEUT\%C3\%93W\%20 POLSKIEGO\%20TOWARZYSTWA
$\% 20$ PSYCHIATRYCZNEGO\%20 uchwalony\%202015_10_17(3).pdf (dostęp: 24.01.2018).

Regulamin Sądu Koleżeńskiego Polskiego Towarzystwa Psychologicznego z dnia 28.11.2015 r., http://www.ptp.org.pl/ modules.php? name $=$ News $\&$ file $=$ article\&sid=26 (dostęp: 24.01.2018).

Statut Polskiego Towarzystwa Psychologicznego z dnia 21.09.2005 ze zmianami, http://www.ptp.org.pl/modules.php?na$\mathrm{me}=$ News\&file $=$ article\&sid=28 (dostęp: 24.01.2018).

Statut Polskiego Towarzystwa Terapii Poznawczej i Behawioralnej $\mathrm{z}$ dnia 
26.11.1998 z późn. zm. http://www. pttpb.pl/dokumenty/statut-towarzystwa/ (dostęp: 24.01.2018).

Ustawa z dnia 8 czerwca 2001 r. o zawodzie psychologa i samorządzie zawodowym psychologów.
Ustawa z dnia 19 sierpnia 1994 r. o ochronie zdrowia psychicznego, tj. z dnia 5 kwietnia $2017 \mathrm{r}$.

Ustawa z dnia 6 listopada 2008 r. o prawach pacjenta i Rzeczniku Praw Pacjenta, tj. z dnia 8 czerwca 2017 r.

\section{BETWEEN CONFIDENTIALITY POLICY AND AN OBLIGATION TO DENOUNCE - DOES POLISH LAW IGNORE OR PROTECT PROFESSIONAL SECRECY OF PSYCHOLOGISTS?}

Abstract: Confidentiality is without a doubt one of the most important rules in psychologist's profession. Polish law guarantees the protection of professional secrecy of psychologists (also in the provisions of the penal code which criminalize its violation). However, the same law (Polish penal code) forces psychologists to break the policy of confidentiality in the case of gathering a reliable information about certain crimes by. The aim of the current pub- lication is to elaborate on the collision of the values of keeping professional secrecy and of public security and justice system. The outcome of the analysis can with certainty be helpful for psychologists in solving a conflict between professional secrecy and a legal obligation regarding reporting a crime.

Keywords: professional secrecy of psychologists, ethics, criminal law. 